\title{
Perancangan Sistem Estimasi untuk Menentukan Biaya Kelayakan Proyek IT
}

\author{
A Development of IT Project Cost Estimation System
}

\author{
Sahirul Muklis*1, Kusrini², Andi Sunyoto ${ }^{3}$ \\ ${ }^{1,2,3}$ Program Pascasarjana Magister Teknik Informatika Universitas Amikom Yogyakarta \\ Jl Ring road Utara, Condongcatur, Sleman, Yogyakarta 55281 \\ E-mail: *1 sahirulmuklis@gmail.com, ${ }^{2}$ kusrini@amikom.ac.id, ${ }^{3}$ andi@amikom.ac.id
}

\begin{abstract}
Abstrak
Proyek IT dianggap gagal karena tidak memberikan manfaat dan tidak sesuai dengan tujuan awal dari proyek. Tingkat kegagalan proyek IT mencapai 19\% dan hanya 29\% yang dianggap berhasil, selebihnya mengalami kendala. Penilaian ini didasarkan pada biaya, waktu dan kesesuaian dengan permintaan pada awal proyek. Untuk mengetahui besarnya biaya, lamanya waktu pengerjaan dalam proyek IT, perlu diperlukan pengukuran terhadap proses yang akan dijalankan. Dalam proyek IT perlu adanya sebauh Estimasi untuk mengukur biaya, waktu dan besarnya ruang lingkup. Estimasi biaya dapat diketahui dengan memperkirakan besarnya ruang lingkup dari proyek IT dengan menggunakan nilai Effort atau nilai usaha proyek IT. Effort dari proyek IT dapat ditentukan dengan beberapa metode contohnya Metode Use Case Point. Penggunaan Metode Use Case Point yang dikolaborasikan dengan Metode Fuzzy dapat membantu dalam mengklasifikasikan nilai dari Use Case Weight yang ada di Use Case Point sehingga besarnya biaya proyek IT mendekati nilai aslinya. Estimasi biaya ini dapat digunakan sebagai salah satu indikator pembantu untuk menilai kelayakan proyek IT.
\end{abstract}

Kata Kunci - Fuzzy, UCP, Estimasi, Biaya Proyek IT

\begin{abstract}
IT projects are considered to be failed because they do not provide benefits and are not in accordance with the project's initial objectives. The failure rate for IT projects reached 19\% and only $29 \%$ were considered successful, the rest experienced problems. This assessment is based on cost, time and compliance with the request at the beginning of the project. To find out the amount of the cost, the length of time spent in the IT project, it is necessary to measure the process to be carried out. In IT projects there needs to be an estimate to measure the cost, time and magnitude of the scope. Cost estimates can be known by estimating the size of the IT project by using the Effort value or the value of the IT project business. Efforts from IT projects can be determined by several methods for example, the Use Case Point Method. The use of the Use Case Point method that is collaborated with the Fuzzy Method can help in classifying the value of Use Case Weight at the Use Case Point so that the amount of IT project costs approaches the original value. This cost estimate can be used as one of the supporting indicators to assess the feasibility of an IT project.
\end{abstract}

Keywords - IT Project, UCP, Effort, Fuzzy 


\section{PENDAHULUAN}

Dalam aktivitas sehari-hari kita sering mendengar atau bahkan menjadi pelaku dari kegiatan proyek. Proyek pembangunan gedung, proyek jalan, proyek pengadaan barang dan jasa, proyek sistem informasi dan lain-lain. Sehingga perlu adanya manajemen dalam penanganan sebuah proyek, baik proyek apapun itu. Manajemen proyek didesain untuk mengatur dan mengontrol sumber daya perusahaan sesuai dengan aktivitas yang terkait dengan efesiensi waktu, biaya, dan performa yang baik. Hal ini memerlukan pengolahan yang baik dan terarah karena suatu proyek pasti mempunyai keterbatasan supaya tujuan akhir dari proyek bisa tercapai sebagai mana semestinya sesuai dengan rancangan awal.

Menurut beberapa professional bidang IT, proyek IT dianggap gagal karena tidak memberikan manfaat bagi perusahaan dimana nilai manfaat dari proyek IT tidak digunakan secara optimal. Dari Standish Group Report 2015 Chaos memaparkan laporan tentang tingkat kesuksesan penanganan proyek it, dimana $29 \%$ project yang ada dinyatakan sukses dinilai dari sisi biaya, waktu, kesesuaian permintaan, dan fungsinya. Kemudian 52\% lainnya mengalami kendala dinilai dari keterlambatan, fitur yang tidak sesuai, biaya yang berlebihan dan fungsi yang tidak sempurna. Tingkat kegagalan dalam proyek TI sendiri adalah 19\%. Inilah data yang didapat dari Standish Group Report 2015 Chaos [1].

Dari data laporan yang dikeluarkan Standish Group Report 2015 Chaos diatas, maka perlu adanya perbaikan sistem perencanaan dalam proyek TI. Terutama dari segi studi kelayakan terhadap perencanaan proyek TI. Salah satu cara untuk memperbaiki penilaian kelayakan dari perencanaan proyek TI dengan menggunakan estimasi nilai usaha proyek atau dengan nilai effort yang dipadu dengan beberapa metode yang tepat. Nilai effort digunakan untuk memberikan prediksi atau keluaran dari sebuah proyek TI yang akan dijalankan dengan meninjau segi teknis, waktu dan biaya. Dimana nilai effort didapat dari data requirement yang dianalisa dan disesuaikan dengan kemampuan dari pemenang lelang proyek. Data informasi akan diolah dengan sistem salah satunya sistem pendukung keputusan, sehingga sistem memberikan alternatif-alternatif yang baik dan bisa digunakan untuk pengambilan keputusan [2].

Penggunaan nilai effort rate dari berbagai penelitian memiliki berbagai variasi dengan dasar faktor penentu yang berbeda-beda. Dalam penelitian yang dilakukan oleh karner nilai effort rate yang digunakan dengan metode use case point sebesar 20 man-hours yang diacu dari tiga data proyek IT [3]. Dari beberapa peneliti lainnya menyebutkan penggunaan nilai effort rate sebesar 20, 24 dan 26 man-hours yang didasarkan pada kompleksitas proyek yang di jalankan dengan dasar Technical Complexity Factor (TCF) [4]. Jika dilihat dari penggunaan sumber daya manusia yang terlibat dalam sebuah proyek IT dapat disimpulkan nilai effort rate berkisar antara 15-30 man-hours. Semakin sering sebuah team mengerjakan proyek IT makan nilai effort rate semakin kecil dengan tingkat compleksitas yang hampir sama. Ochodek menyebutkan nilai effort rate bisa berkisar 4 sampai 35 man-hours tergantung pada jumlah proyek yang sudah dikerjakan [5]. Dari beberapa pendapat diatas nilai effort rate yang sering digunakan untuk perhitungan estimasi effort yaitu nilai 20 man-hours sesuai dengan temuan karner.

Logika fuzzy adalah salah satu komponen yang terdapat dalam bentuk soft computing. Logika fuzzy untuk pertama kali dikenalkan pada tahun 1965 oleh prof. Lotfi A. Zaedah dengan menggabungkan teory dari himpunan fuzzy [6]. Bila dibandingkan dengan logika konvensional, kelebihan logika fuzzy ialah mampu menerapkan penalaran dalam proses secara bahasa sehingga mempermudah perancangan [7].

Metode use case point dapat memberikan perkiraan effort yang hampir mendekati nilai effort aslinya dengan memadukan metode use case point dengan logika fuzzy. Penggunaa metode fuzzy use case point bergantung pada pengalaman tim pengembang dalam menjalakan proyek IT. Metode ini sangat mudah digunakan namun bisa menjadi kurang akurat ketika penentuan kompleksitas faktor bersifat linier bila melihat nilai transaksi pada setiap use case. Metode ini menghasilkan nilai effort yang lebih mendekati nilai effort actual dari sebuah proyek IT [8].

Pada penelitian kali ini nilai effort yang digunakan adalah hasil dari metode fuzzy use case point atau metode modifikasi dari use case point. Setelah nilai effort didapat, maka 
pembagian nilai effort disesuaikan dengan aktivitas development. Mengacu pada penelitian [9] aktivitas development yang digunakan dibagi dalam tiga aktivitas. Fase pertama development dibagi kedalam bebrapa aktivitas yaitu pengumpulan data, spesifikasi, desain, implementasi dan pembuatan. Semua aktivitas pada fase pertama ini berjumlah $42 \%$ dari total estimasi effort yang didapat. Aktivitas fase kedua ini meliputi management proyek, pengaturan proyek, dokumentasi dan support training. Pada fase kedua semua aktivitas berjumlah $21 \%$ dari total estimasi nilai effort yang didapat. Aktivitas Fase Ketiga meliputi kualitas dan testing, aktivitas integrase testing, penjaminan kualitas, evaluasi dan pemeliharaan. Pada fase ketiga ini pembagian nilai effort sebesar 37\% dari total nilai estimasi nilai effort. Dengan pembagian terhadap beberapa fase development proyek IT ini bisa dilihat alokasi biaya pada setiap aktivitas development [9].

\section{METODE PENELITIAN}

Penelitian ini menggunakan metode penelitian research and development. Metode Penelitian ini digunakan untuk membuktikan perancangan sistem dengan metode tertentu dapat dianalisa dan dijadikan patokan dalam membuat sebuah sistem estimasi biaya proyek IT. Dalam penelitian yang akan dilakukan, peneliti mempunyai tujuan untuk merancang sebuah sistem estimasi biaya untuk menentukan biaya kelayakan proyek TI dengan menerapkan metode tertentu.

\subsection{Alur Penelitian}



Gambar 1. Alur Penelitian 
Citec Journal, Vol. 5, No. 2, Februari 2018 - April 2018

ISSN: 2460-4259

Proses penelitian dilakukan dengan langkah-langkah logis yang telah disusun dan direncanakan oleh penulis. Setiap langkah tersebut merupakan tahapan yang saling berhubungan, dimana suatu proses yang dilakukan merupakan bagian dari tahapan yang menentukan proses selanjutnya. Serangkaian proses tersebut digambarkan dalam tahapan kegiatan penelitian seperti pada Gambar 1.

\subsection{Metode Use Case Point}

Metode use case point (UCP) adalah metode yang mempunyai kemampuan untuk memberikan estimasi effort yang diperlukan untuk membuat suatu proyek berdasarkan jumlah dan komplesitas usecase yang dimiliki oleh proyek perangkat lunak tersebut [3].

Langkah-langkah yang dilakukan dalam proses estimasi effort dengan Fuzzy Use Case Point digambarkan dalam Gambar 2.

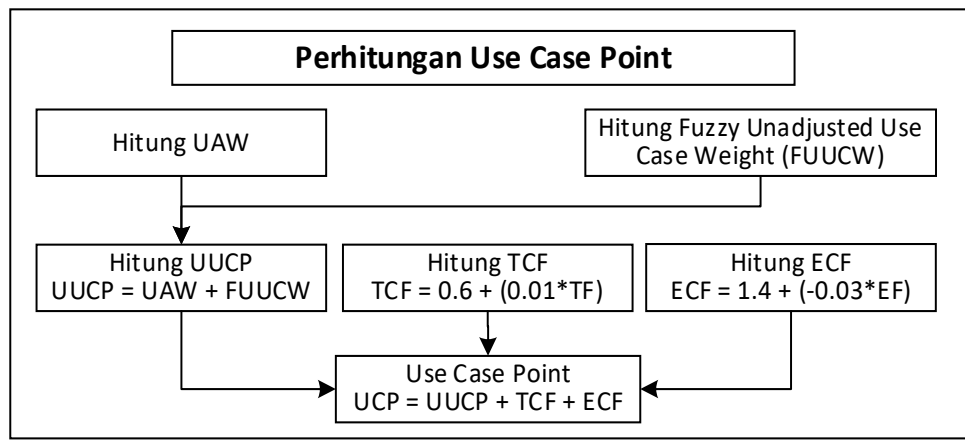

Gambar 2. Langkah-langkah Metode Use Case Point (UCP)

Untuk mengestimasi proyek menggunakan use case points, terlebih dahulu dibuat use case diagram. Pada Tabel 1 dapat dilakukan klasifikasi actor untuk mengetahui nilai Unadjusted Actor Weight (UAW) dengan cara mengkalikan jumlah actor dengan weighting faktor.

Tabel 1. Unadjusted Actor Weighting

\begin{tabular}{|l|l|c|}
\hline \multicolumn{1}{|c|}{ Actor Type } & \multicolumn{1}{|c|}{ Description } & Weighting Factor \\
\hline Simple & External system with well-defined API & 1 \\
\hline Average & External system using a protocol based interface & 2 \\
\hline Complex & Human & 3 \\
\hline
\end{tabular}

Selain aktor, setiap use case diklasifikasikan berdasarkan jumlah transaksinya. Hal ini digunakan untuk menghitung Unadjusted Use Case Weight (UUCW). Cara menghitung UUCW sama dengan UAW yaitu masing-masing use case di bagi dalam 3 kelompok yaitu simple, average, dan complex. Tergantung dari jumlah transaksi yang dilakukan pada setiap use case. Untuk penjelasan lebih detail tentang diskripsi use case dapat dilihat pada Tabel 2.

Tabel 2. Unadjusted Use Case Weight

\begin{tabular}{|c|c|c|}
\hline Use Case & Deskripsi Transaksi & Bobot Faktor \\
\hline Simple & $1-3$ & 5 \\
\hline Average & $4-7$ & 10 \\
\hline Complex & $>7$ & 15 \\
\hline
\end{tabular}

Total Unadjusted Use Case Weights (UUCW) didapat dari menghitung jumlah use case dari masing-masing tingkat kompleksitas dikali dengan total factor setiap use case. Kemudian jumlahkan UAW dan UUCW untuk mendapatkan Unadjusted Use Case Point (UUCP) dengan persamaan 1. 


$$
U U C P=U A W+U U C W
$$

Pada perhitungan nilai use case point (UCP) juga terdapat nilai complexity factor. Complexity factor merupakan faktor yang mempunyai pengaruh secara langsung pada proyek IT. Complexity factor dibagi menjadi 2 yaitu Technical Complexity Factor (TCF) dan Environmental Complexity Factor (ECF).

\subsubsection{Technical Complexity Factor (TCF)}

TCF merupakan salah satu faktor yang diterapkan pada perkiraan ukuran perangkat lunak untuk memperhitungkan pertimbangan teknis dari sistem. Technical complexity factor dibobot tergantung dari bagaimana tingkat kesulitan sistem yang akan dibangun. Selain itu dilakukan pembobotan yang berbeda berdasarkan pengalaman pada proyek. Ada 13 faktor teknis yang diperhitungkan untuk memperkirakan ukuran perangkat lunak pada metode use case points, seperti pada Tabel 3.

Tabel 3. Technical Factor

\begin{tabular}{|c|l|c|}
\hline No & \multicolumn{1}{|c|}{ Technical Factor } & Bobot \\
\hline TCF01 & Distributed System Required & 2 \\
\hline TCF02 & Response Time Is Important & 1 \\
\hline TCF03 & End User Efficiency & 1 \\
\hline TCF04 & Complex Internal Processing Required & 1 \\
\hline TCF05 & Reusable Code Must Be A Focus & 1 \\
\hline TCF06 & Installation Easy & 0.5 \\
\hline TCF07 & Usability & 0.5 \\
\hline TCF08 & Cross-Platform Support & 2 \\
\hline TCF09 & Easy to Change & 1 \\
\hline TCF10 & Highly Concurrent & 1 \\
\hline TCF11 & Costum Security & 1 \\
\hline TCF12 & Dependence On Third-Part Code & 1 \\
\hline TCF13 & User Training & \\
\hline
\end{tabular}

Nilai-nilai pada Technical factor tersebut dikalikan dengan bobot nilai masing-masing. Penilaian dilakukan pada setiap faktor bergantung pada seberapa pengaruh fator terhadap proyek IT. Dengan rentang nilai 0-5 untuk masing-masing faktor yang berjumlah 13 seperti pada Tabel 3. Hasil perkalian nilai dan bobot kemudian dijumlahkan untuk mendapat nilai total TF yang akan digunakan utuk mendapatkan nilai Technical Complexity Factor (TCF) seperti yang tertulis pada persamaan ke-2.

$$
T C F=0.6+\left(0.01 \sum_{i=1}^{13} f i * W\right)
$$

\subsubsection{Environmental Complexity Factor (ECF)}

Untuk menghitung EF, nilai dari masing-masing faktor lingkungan dihitung berdasarkan tingkat pengalaman tim. Hal ini ditentukan dengan menetapkan skor antara 0 (tidak ada pengalaman) dan 5 (ahli) untuk setiap 8 faktor lingkungan yang tercantum dalam Tabel 4. 
Citec Journal, Vol. 5, No. 2, Februari 2018 - April 2018

Tabel 4. Environmental Factor

\begin{tabular}{|c|l|c|}
\hline No & \multicolumn{1}{|c|}{ Environmental Factor } & Bobot \\
\hline EF01 & Familiarity with system development process being used & 1.5 \\
\hline EF02 & Application experience & 0.5 \\
\hline EF03 & Object-oriented experience & 1 \\
\hline EF04 & Lead analyst capability & 0.5 \\
\hline EF05 & Motivation & 1 \\
\hline EF06 & Requirements stability & 2 \\
\hline EF07 & Part time staff & -1 \\
\hline EF08 & Difficulty of programming language & -1 \\
\hline
\end{tabular}

Nilai-nilai pada Environmental factor tersebut dikalikan dengan bobot nilai masingmasing. Penilaian pada setiap faktor tergantung dengan pengaruh faktor tersebut terhadap proyek IT. Dengan rentang nilai 0-5 untuk masing-masing faktor yang berjumlah 8 seperti pada Tabel 4. Hasil perkalian nilai dan bobot kemudian dijumlahkan untuk mendapat nilai total EF yang akan digunakan utuk mendapatkan nilai Environmental Complexity Factor (ECF) seperti yang tertera pada persamaan ke-3.

$$
E C F=1.4+(-0.03 * E F)
$$

Sehingga kita bisa mendapatkan nilai dari use case point (UCP) yang didapatkan melalui perkalian UUCP, TCF, dan ECF Seperti pada persamaan ke-4.

$$
U C P=U U C P+T C F+E C F
$$

Nilai UCP merupakan nilai ukuran software yang didapatkan dari hasil perhitungan kompleksitas software berdasarkan use case nya, namun nilai ini belum memiliki manfaat untuk dapat digunakan dalam estimasi proyek, oleh karena itu nilai UCP perlu diterjemahkan menjadi nilai effort.

Effort rate (ER) merupakan tingkat usaha yang dilakukan dalam menyelesaikan sebuah use case. Karner menentukan nilai ER pertama kali ialah 20 man-hours. Ada beberapa penelitian lain juga menetukan nilai ER beragam. Clemmons mengajukan nilai ER 15 - 30 tergantung pengalaman yang dimiliki oleh tim.

Setelah kita menentukan nilai effort rate yang digunakan, maka kita dapat menghitung nilai effort dalam pengembangan perangkat lunak. Satuan effort yang dihasilkan ialah orangperjam (man-hours). Persamaan 5 merupakan formula dalam penentuan effort.

$$
\text { Effort }=U C P * \text { Efryefort Rate }
$$

Dengan mendapatkan nilai effort maka kita dapat lebih mudah menghitung berapa sumber daya yang dibutuhkan dalam proyek, sumber daya bisa berupa biaya maupun SDM.

\subsection{Metode Fuzzy Use Case Points}

Dalam Penelitian ini menggunakan metode Use Case Point yang di modifikasi dengan logika Fuzzy untuk memberikan nilai klasifikasi Use Case yang digunakan. Logika fuzzy yang digunakan merupakan fuzzy inference system metode mamdani, terdiri dari variable masukan dan keluaran yang masig-masing terdiri dari tiga kurva segitiga, berturut-turut bisa dilihat pada Gambar 3 sampai Gambar 5. 


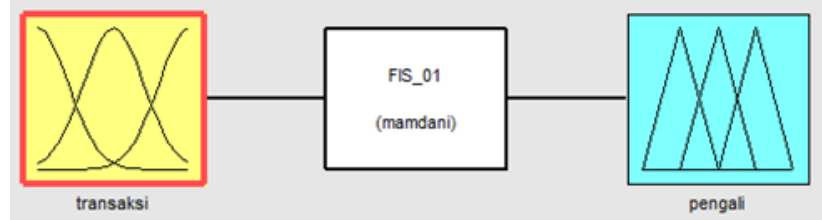

Gambar 3. FIS Metode Mamdani

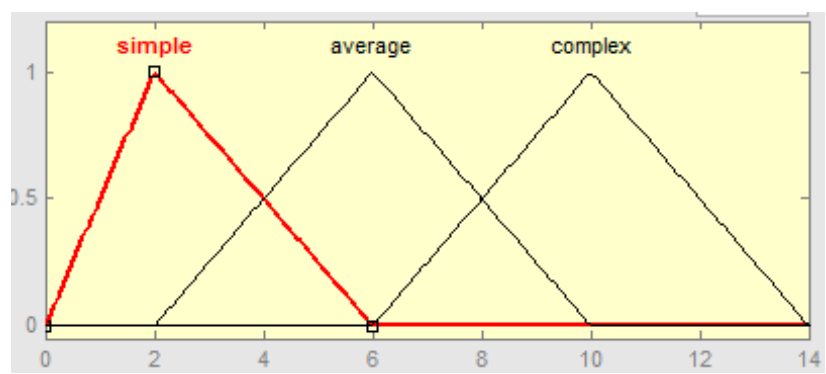

Gambar 4. Variable Masukan

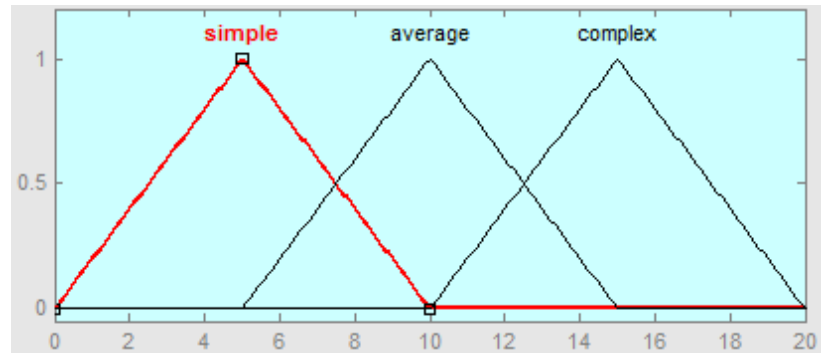

Gambar 5. Variable Keluaran

Logika fuzzy juga memerlukan beberapa pengaturang rules seperti berikut:

a. If proses adalah simple maka pengali adalah simple

$b$. If proses adalah average maka pengali adalah average

c. If proses adalah complex maka pengali adalah complex

Dari hasil pengujian logika fuzzy dengan memberikan nilai masukkan berupa jumlah transaksi. Akan menghasilkan nilai sesuai dengan Tabel 5.

Tabel 5. Hasil Keluaran Logika Fuzzy

\begin{tabular}{|c|c|}
\hline Masukan Nilai & Nilai Keluaran \\
\hline 1 & 5 \\
\hline 2 & 5 \\
\hline 3 & 6,45 \\
\hline 4 & 7,5 \\
\hline 5 & 8,55 \\
\hline 6 & 10 \\
\hline 7 & 11,4 \\
\hline 8 & 12,5 \\
\hline 9 & 13,6 \\
\hline 10 & 15 \\
\hline 11 & 15 \\
\hline 12 & 15 \\
\hline
\end{tabular}




\section{HASIL DAN PEMBAHASAN}

Pada penelitian kali ini, studi kasus yang menjadi bahan penelitian adalah proyek pengembangan perangkat lunak. Untuk mempermudah penyusunan table maka akan diberikan inisialisasi terhadap beberapa proyek yang akan menjadi sample pengujian estimasi biaya proyek perangkat lunak. Berikut merupakan sample proyek yang akan diestimasi besaran biaya proyek perangkat lunak. Pada tabel 6 merupakan sample proyek yang akan diestimasi besaran biaya proyek perangkat lunak.

Tabel 6. Inisialisasi Nama Proyek

\begin{tabular}{|c|l|c|}
\hline No & \multicolumn{1}{|c|}{ Nama Proyek } & Inisial \\
\hline 1 & Sistem Informasi Perpustakaan & A \\
\hline 2 & Sistem Informasi Akademik & B \\
\hline 3 & Sistem Monitoring Depot Air & C \\
\hline 4 & Sistem Akademik Sekolah & D \\
\hline 5 & Website Resmi Pemerintahan & E \\
\hline 6 & Sistem Kepegawaian & F \\
\hline 7 & Bursa Kerja Online Disnaker & G \\
\hline 8 & Website Penerimaan SIswa Online & H \\
\hline
\end{tabular}

\subsection{Distribusi Nilai Effort}

Estimasi nilai effort yang diperoleh akan didistribusikan ke masing-masing kegiatan proses pengembangan proyek perangkat lunak dan akan disesuaikan dengan presentase dari masing-masing proses pengembangan yag dapat dilihat pada Tabel 7. Presentase ini akan digunakan untuk menentukan estimasi besaran biaya proyek. Dalam sistem development proyek IT mempunyai beberapa aktivitas kelompok yaitu Software Development, Ongoing, dan Quality Testing. Dari aktivitas kelompok tersebut memiliki peran masing-masing dan memiliki nilai effort yang berbeda-beda pada setiap aktifitasnya sesuai dengan presentase yang sudah diberikan [11].

Tabel 7. Presentase Effort

\begin{tabular}{|l|c|}
\hline \multicolumn{1}{|c|}{ Kelompok Aktivitas } & Effort (\%) \\
\hline Software Development & \\
\hline Requirements & 7,5 \\
\hline Specifications \& Design & 17,5 \\
\hline Coding & 10 \\
\hline Integration Testing & 7 \\
\hline On Going Activity & \\
\hline Project Management & 7 \\
\hline Configuration Management & 4 \\
\hline Documentation & 4 \\
\hline Acceptance \& Deployment & 6 \\
\hline Quality and Testing & \\
\hline Quality Assurance \& Control & 12,5 \\
\hline Evaluation and Testing & 24,5 \\
\hline
\end{tabular}




\subsection{Perhitungan Use Case Point}

\subsubsection{Unadjusted Use Case Point(UUCP)}

Untuk memperoleh nilai dari unadjusted use case point kita perlu melakukan perhitungan unadjusted actor weight(UAW) dan perhitungan unadjusted use case weight yang di modifikasi dengan logika Fuzzy mamdani(FUUCW). Dari kedua penjumlahan UAW dan FUUCW ini lah nilai UUCP akan didapatkan. Nilai UUCP yang telah dimodifikasi dengan Fuzzy dapat kita lihat pada Table 8.

Tabel 8. Nilai Unadjusted Use Case Point

\begin{tabular}{|c|c|c|c|}
\hline Inisial Proyek & UAW & FUUCW & UUCP \\
\hline A & 12.00 & 112,5 & 121,5 \\
\hline B & 16.00 & 123,6 & 139,6 \\
\hline C & 9.00 & 67,5 & 76,5 \\
\hline D & 14.00 & 153,9 & 167,9 \\
\hline E & 12.00 & 247,8 & 259,8 \\
\hline F & 12.00 & 123,6 & 135,6 \\
\hline G & 12.00 & 112,5 & 124,5 \\
\hline H & 9.00 & 103,6 & 112,6 \\
\hline
\end{tabular}

\subsubsection{Technical Complexity Factor (TCF)}

Pemberian nilai pada Technical Complexity Factor untuk menerapkan salah satu faktor pada perkiraan ukuran perangkat lunak untuk memperhitungkan pertimbangan teknis dari sistem. Faktor ini menggambarkan ekspektasi yang diharapkan user terhadap software yang akan dibangun. Technical complexity factor dibobot tergantung dari bagaimana tingkat kesulitan sistem yang akan dibangun. Untuk setiap proyek penelian akan berbeda-beda tergantung dengan user yang memberikan proyek IT. Hasil perhitungan nilai TCF terdapat pada Tabel 9.

Tabel 9. Nilai Technical Complexity Factor

\begin{tabular}{|c|c|}
\hline Inisial & TCF \\
\hline A & 1,16 \\
\hline B & 1,09 \\
\hline C & 1,05 \\
\hline D & 1,17 \\
\hline E & 1,045 \\
\hline F & 1,005 \\
\hline G & 1,045 \\
\hline H & 1,16 \\
\hline
\end{tabular}

\subsubsection{Environmental Complexity Factor (ECF)}

Pemberian nilai pada Environmental Complexity Factor untuk setiap proyek akan berbeda-beda tergantung dengan pengalaman yang dimiliki oleh tim pengembang dan manajemen tim yang akan melaksanakan proyek IT. Nilai ECF dapat dilihat pada Table 10. 
Citec Journal, Vol. 5, No. 2, Februari 2018 - April 2018

Tabel 10. Nilai Environmental Complexity Factor

\begin{tabular}{|c|c|}
\hline Inisial Proyek & ECF \\
\hline A & 0,85 \\
\hline B & 0,85 \\
\hline C & 0,76 \\
\hline D & 0,85 \\
\hline E & 0,875 \\
\hline F & 0,995 \\
\hline G & 0,65 \\
\hline H & 0,76 \\
\hline
\end{tabular}

\subsection{Use Case Point (UCP)}

Untuk menghitung nilai UCP kita harus mengalikan UUCP, TCF, dan ECF. Seperti pada Rumus (4). Maka kita akan mendapatkan nilai UCP seperti pada Tabel 11.

Tabel 11. Nilai Unadjusted Use Case Point

\begin{tabular}{|c|c|c|c|c|}
\hline Inisial & UUCP & TCF & ECF & UCP \\
\hline A & 121,5 & 1,16 & 0,85 & 119,799 \\
\hline B & 139,5 & 1,09 & 0,85 & 129,3394 \\
\hline C & 76,5 & 1,05 & 0,76 & 61,047 \\
\hline D & 167,9 & 1,17 & 0,85 & 166,9766 \\
\hline E & 259,8 & 1,045 & 0,875 & 237,5546 \\
\hline F & 135,6 & 1,005 & 0,995 & 135,5966 \\
\hline G & 124,5 & 1,045 & 0,65 & 84,56663 \\
\hline H & 112,6 & 1,16 & 0,76 & 99,26816 \\
\hline
\end{tabular}

\subsection{Estimasi Effort}

Dari hasil nilai UCP yang ada kita dapat gunakan untuk mencari nilai Estimasi dari Effort dengan mengkalikan UCP dengan Effort Rate seperti pada Rumus (5). Effort rate yang akan digunakan mengacu pada penelitian yang dilakukan oleh karner yaitu sebesar 20 man-hours[3]. Nilai estimasi effort dapat dilihat pada Tabel 12.

Tabel 12. Nilai Unadjusted Use Case Point

\begin{tabular}{|c|c|c|c|}
\hline Inisial & UCP & Effort & Estimasi \\
\hline A & 119,799 & 20 & 2395,98 \\
\hline B & 129,3394 & 20 & 2586,788 \\
\hline C & 61,047 & 20 & 1220,94 \\
\hline D & 166,9766 & 20 & 3339,531 \\
\hline E & 237,5546 & 20 & 4751,093 \\
\hline F & 135,5966 & 20 & 2711,932 \\
\hline G & 84,56663 & 20 & 1691,333 \\
\hline H & 99,26816 & 20 & 1985,363 \\
\hline
\end{tabular}

\subsection{Estimasi Biaya}

Dengan diketahuinya nilai estimasi effort maka dapat dilanjutkan dengan menghitung estimasi biaya dengan mendistribusikan estimasi effort sesuai dengan persentase kegiatan yang mengacu pada penelitian yang terlihat pada tabel 13 [11]. Namun estimasi biaya yang disusulkan oleh shaleh hanya terletak pada estimasi biaya proses development belum menyakut pada target 
keuntungan yang akan di capai, juga belum menambahkan pilihan ada tidaknya penambahan hardware yang akan digunakan pada proyek IT, dan juga perhitungan Pajak Pertambahan Nilai (PPN) yang berlaku di Indonesia. Pada penelitian ini menambahkan beberapa kompenen biaya untuk mengestimasi biaya dari proyek IT. Estimasi biaya dapat dilihat di Tabel 14.

Tabel 13. Presentase Effort

\begin{tabular}{|c|c|c|c|c|c|c|c|c|c|}
\hline Kelompok Aktivitas & \multirow{2}{*}{ Effort } & \multirow[t]{2}{*}{ A } & \multirow[t]{2}{*}{ B } & \multirow[t]{2}{*}{ C } & \multirow[t]{2}{*}{ D } & \multirow[t]{2}{*}{$\mathbf{E}$} & \multirow[t]{2}{*}{$\mathbf{F}$} & \multirow[t]{2}{*}{$\mathbf{G}$} & \multirow[t]{2}{*}{$\mathbf{H}$} \\
\hline Software Development & & & & & & & & & \\
\hline Requirements & 0,075 & 179,6985 & 194,0091 & 91,5705 & 250,464825 & 356,3319375 & 203,394915 & 126,8499375 & 148,90224 \\
\hline Specifications \& Design & 0,175 & 419,2965 & 452,6879 & 213,6645 & 584,417925 & 831,4411875 & 474,588135 & 295,9831875 & 347,43856 \\
\hline Coding & 0,1 & 239,598 & 258,6788 & 122,094 & 333,9531 & 475,10925 & 271,19322 & 169,13325 & 198,53632 \\
\hline Integration Testing & 0,07 & 167,7186 & 181,07516 & 85,4658 & 233,76717 & 332,576475 & 189,835254 & 118,393275 & 138,975424 \\
\hline \multicolumn{10}{|l|}{ On Going Activity } \\
\hline Project Management & 0,07 & 167,7186 & 181,07516 & 85,4658 & 233,76717 & 332,576475 & 189,835254 & 118,393275 & 138,975424 \\
\hline Configuration Management & 0,04 & 95,8392 & 103,47152 & 48,8376 & 133,58124 & 190,0437 & 108,477288 & 67,6533 & 79,414528 \\
\hline Documentation & 0,04 & 95,8392 & 103,47152 & 48,8376 & 133,58124 & 190,0437 & 108,477288 & 67,6533 & 79,414528 \\
\hline Acceptance \& Deployment & 0,06 & 143,7588 & 155,20728 & 73,2564 & 200,37186 & 285,06555 & 162,715932 & 101,47995 & 119,121792 \\
\hline \multicolumn{10}{|l|}{ Quality and Testing } \\
\hline Quality Assurance \& Control & 0,125 & 299,4975 & 323,3485 & 152,6175 & 417,441375 & 593,8865625 & 338,991525 & 211,4165625 & 248,1704 \\
\hline Evaluation and Testing & 0,245 & 587,0151 & 633,76306 & 299,1303 & 818,185095 & 1164,017663 & 664,423389 & 414,3764625 & 486,413984 \\
\hline
\end{tabular}

Tabel 14. Estimasi Biaya Proyek IT

\begin{tabular}{|c|c|c|c|c|c|c|c|c|c|}
\hline $\begin{array}{l}\text { Kelompok } \\
\text { Aktivitas }\end{array}$ & \multirow{2}{*}{$\begin{array}{l}\text { Upah } \\
\text { (RP) }\end{array}$} & \multirow{2}{*}{$\begin{array}{c}\text { A } \\
(\mathbf{R p})\end{array}$} & \multirow{2}{*}{$\begin{array}{c}\text { B } \\
(\mathbf{R p})\end{array}$} & \multirow{2}{*}{$\begin{array}{c}\mathrm{C} \\
(\mathbf{R p})\end{array}$} & \multirow{2}{*}{$\begin{array}{c}\text { D } \\
\text { (Rp) }\end{array}$} & \multirow{2}{*}{$\begin{array}{c}\mathbf{E} \\
(\mathbf{R p})\end{array}$} & \multirow{2}{*}{$\begin{array}{c}\text { F } \\
(\mathbf{R p})\end{array}$} & \multirow{2}{*}{$\begin{array}{c}\text { G } \\
(\mathbf{R p})\end{array}$} & \multirow{2}{*}{$\begin{array}{c}\text { H } \\
(\mathbf{R p})\end{array}$} \\
\hline \begin{tabular}{|l|} 
Software \\
Development
\end{tabular} & & & & & & & & & \\
\hline Requirements & 25065 & $4.504 .142,90$ & $4.862 .838,09$ & $2.295 .214,58$ & $6.277 .900,84$ & $8.931 .460,01$ & $5.098 .093,54$ & $3.179 .493,68$ & $3.732 .234,65$ \\
\hline $\begin{array}{l}\text { Specifications } \\
\text { and Design } \\
\end{array}$ & 43750 & $18.344 .221,88$ & $19.805 .095,63$ & $9.347 .821,88$ & 25.568.284,22 & $36.375 .551,95$ & 20.763.230,91 & $12.949 .264,45$ & $15.200 .437,00$ \\
\hline Coding & 50000 & $11.979 .900,00$ & $12.933 .940,00$ & $6.104 .700,00$ & $16.697 .655,00$ & $23.755 .462,50$ & $13.559 .661,00$ & $8.456 .662,50$ & $9.926 .816,00$ \\
\hline $\begin{array}{l}\text { Integration } \\
\text { Testing }\end{array}$ & 10937 & $1.834 .338,33$ & $1.980 .419,02$ & $934.739,45$ & 2.556.711,54 & 3.637.388,91 & $2.076 .228,17$ & $1.294 .867,25$ & $1.519 .974,21$ \\
\hline \multicolumn{10}{|l|}{$\begin{array}{l}\text { On Going } \\
\text { Activity }\end{array}$} \\
\hline \begin{tabular}{|l|} 
Project \\
Management
\end{tabular} & 156250 & $26.206 .031,25$ & $28.292 .993,75$ & $13.354 .031,25$ & $36.526 .120,31$ & $51.965 .074,22$ & $29.661 .758,44$ & $18.498 .949,22$ & $21.714 .910,00$ \\
\hline \begin{tabular}{|l|} 
Configuration \\
Management \\
\end{tabular} & 118750 & $11.380 .905,00$ & $12.287 .243,00$ & $5.799 .465,00$ & $15.862 .772,25$ & $22.567 .689,38$ & $12.881 .677,95$ & $8.033 .829,38$ & $9.430 .475,20$ \\
\hline Documentation & 3125 & $299.497,50$ & $323.348,50$ & $152.617,50$ & $417.441,38$ & $593.886,56$ & $338.991,53$ & $211.416,56$ & $248.170,40$ \\
\hline $\begin{array}{l}\text { Acceptance and } \\
\text { Deployment }\end{array}$ & 243750 & $35.041 .207,50$ & $37.831 .774,50$ & $17.856 .247,50$ & $48.840 .640,88$ & $69.484 .727,81$ & $39.662 .008,43$ & $24.735 .737,81$ & $29.035 .936,80$ \\
\hline \multicolumn{10}{|l|}{$\begin{array}{l}\text { Quality and } \\
\text { Testing }\end{array}$} \\
\hline \begin{tabular}{|l|} 
Quality \\
Assurance and \\
Control \\
\end{tabular} & 14583 & $4.367 .572,04$ & 4.715.391,18 & $2.225 .621,00$ & $6.087 .547,57$ & $8.660 .647,74$ & 4.943.513,41 & $3.083 .087,73$ & $3.619 .068,94$ \\
\hline \begin{tabular}{|l|} 
Evaluation and \\
Testing \\
\end{tabular} & 204166 & $119.848 .524,91$ & 129.392.868,91 & $61.072 .236,83$ & $167.045 .578,11$ & $237.652 .830,08$ & $135.652 .665,64$ & $84.601 .584,84$ & $99.309 .197,46$ \\
\hline \multicolumn{2}{|c|}{ Hardware } & 15.000 .000 & 50.000 .000 & - & 30.000 .000 & & 15.000 .000 & - & 25.000 .000 \\
\hline \multicolumn{2}{|c|}{\begin{tabular}{|l} 
Keuntungan \\
Perusahaan(25\%)
\end{tabular}} & $62.201 .585,33$ & 75.606.478,14 & $29.785 .673,75$ & $88.970 .163,02$ & $115.906 .179,79$ & $69.909 .457,25$ & $41.261 .223,36$ & $54.684 .305,16$ \\
\hline \multicolumn{2}{|c|}{ PPN 10\% } & $6.220 .158,53$ & $7.560 .647,81$ & $2.978 .567,37$ & $8.897 .016,30$ & \begin{tabular}{|l|}
$11.590 .617,98$ \\
\end{tabular} & $6.990 .945,73$ & 4.126.122,34 & $5.468 .430,52$ \\
\hline \multicolumn{2}{|c|}{ Total Estimasi Biaya } & $317.228 .085,16$ & $385.593 .038,53$ & $151.906 .936,12$ & $453.747 .831,41$ & $591.121 .516,94$ & 356.538.231,99 & $210.432 .239,12$ & 278.889.956,34 \\
\hline
\end{tabular}


Dalam Tabel 14 estimasi biaya menerapkan jumlah SDM yang sama dalam menangani sebuah proyek IT. Estimasi biaya proyek IT ini akan semakin besar ketika manager proyek menerapkan lebih banyak dalam sebuah proyek IT. Estimasi biaya proyek IT dalam Tabel 14 menggunakan standard gaji yang dikeluarkan oleh Kelly Indonesia dengan judul Salary Guide 2016 [10].

Tabel 15. Perbandingan Biaya Estimasi dan Biaya Sebenarnya

\begin{tabular}{|r|l|r|r|r|r|}
\hline No & \multicolumn{1}{|c|}{ Nama Proyek } & $\begin{array}{c}\text { Biaya } \\
(\mathrm{Rp})\end{array}$ & $\begin{array}{c}\text { Estimasi Biaya } \\
(\mathrm{Rp})\end{array}$ & \multicolumn{1}{|c|}{$\begin{array}{c}\text { Selisih } \\
(\mathrm{Rp})\end{array}$} & Persentase \\
\hline 1 & Sistem Informasi Perpustakaan & 277.800 .000 & $317.228 .085,16$ & $(39.428 .085,16)$ & $-14 \%$ \\
\hline 2 & Sistem Informasi Akademik & 569.855 .000 & $385.593 .038,53$ & $184.261 .961,47$ & $32 \%$ \\
\hline 3 & Sistem Monitoring Depot Air & 199.990 .000 & $151.906 .936,12$ & $48.083 .063,88$ & $24 \%$ \\
\hline 4 & Sistem Akademik Sekolah & 400.000 .000 & $453.747 .831,41$ & $(53.747 .831,41)$ & $-13 \%$ \\
\hline 5 & Website Resmi Pemerintahan & 625.625 .000 & $591.121 .516,94$ & $34.503 .483,06$ & $6 \%$ \\
\hline 6 & Sistem Kepegawaian & 531.430 .357 & $356.538 .231,99$ & $174.892 .124,61$ & $33 \%$ \\
\hline 7 & Bursa Kerja Online Disnaker & 199.110 .000 & $210.432 .239,12$ & $(11.322 .239,12)$ & $-6 \%$ \\
\hline 8 & Website Penerimaan SIswa Online & 340.000 .000 & $278.889 .956,34$ & $61.110 .043,66$ & $18 \%$ \\
\hline
\end{tabular}

Tabel 15 merupakan hasil estimasi biaya yang diukur dengan biaya yang disediakan oleh pemilik proyek IT. Dari data diatas ada 3 buah proyek yang estimasi biaya melebih diaya yang disediakan da nada 5 proyek mempunyai nilai estimasi dibawah biaya yang disediakan. Dari contoh data proyek diatas jumlah team yang digunakan untuk masing-masing proyek adalah sama.

\section{KESIMPULAN}

Kesimpulan yang bisa diambil dari penelitian estimasi biaya proyek IT ini ialah

1. Dengan menggunakan metode fuzzy use case point ada 3 buah proyek yang estimasi biaya melebih diaya yang disediakan dan ada 5 proyek mempunyai nilai estimasi di bawah biaya yang disediakan.

2. Besarnya estimasi biaya tergantung dari beberapa komponen seperti kegiatan proses development, biaya hardware yang akan ditambahkan dalam proyek IT, dan keuntungan yang akan diambil oleh perusahaan.

\section{SARAN}

Agar penelitian ini bisa berkembang adapun saran yang dapat diusulkan.

1. Dapat menerapkan metode Function Points digabungkan dengan metode fuzzy untuk mengukur effort yang dibutuhkan dalam mengembangkan perangkat lunak.

2. Aktivitas pengembangan perangkat lunak akan mempengaruhi besaran biaya dan effort yang digunakan.

\section{DAFTAR PUSTAKA}

[1] Chaos Manifiesto. 2015. Think Big, Act Small. The Standish Group. Boston.

[2] Putra, P., dan Hardiyanti D.Y. 2011. Penentuan Penerima Beasiswa dengan Menggunakan Fuzzy Multiple Atribute Decission Making. Jurnal Sistem Informasi, Vol. 3 No. 1, Hal 286293.

[3] Karner, G., 1993. Resource Estimation for Objectory Projects. Objective Systems SF AB. 
[4] Schneider, G., Winters, J. 1998. Applying Use Cases-A Practical Guide. Addison-Wesley, Boston

[5] Ochodek, M., Nawrocki, J., Kwarciak, K., 2011, Simplifying Effort Esimation Based on Use Case Points. Information and Software Technology. Vol. 53, No. 3, Hal 200-213.

[6] Daniati, E. 2016. Logika Fuzzy Model Tahani untuk Rekomendasi Pilihan Kursus di Kampung Inggris Pare Kediri. Citec Journal, Vol. 3, No. 3. Hal. 200 - 213.

[7] Zaki, A. Santoso, H. A., 2016, Model Fuzzy Tsukamoto untuk Klasifikasi dalam Prediksi Krisi Energi di Indonesia. Citec Journal. Vol. 3, No. 3, hal. 185-196.

[8] Hariyanto, M., Romi, S. W., 2015, Estimasi Proyek Pengembangan Perangkat Lunak dengan Fuzzy Use Case Point. Journal of Software Engineering, Vol. 1, No.1, Hal 54 - 63.

[9] Saleh, K., 2011, Effort and Cost Allocation in Medium to Large Software Development Projects. International Journal of Computers, Vol. 5 No.1, Hal. 74-79.

[10] Kelly, 2018, Indonesia 2018 SALARY GUIDE. https://www.michaelpage.co.id/sites/ michaelpage.co.id/files/Indonesia-MP-Salary-Benchmark-2018.pdf 